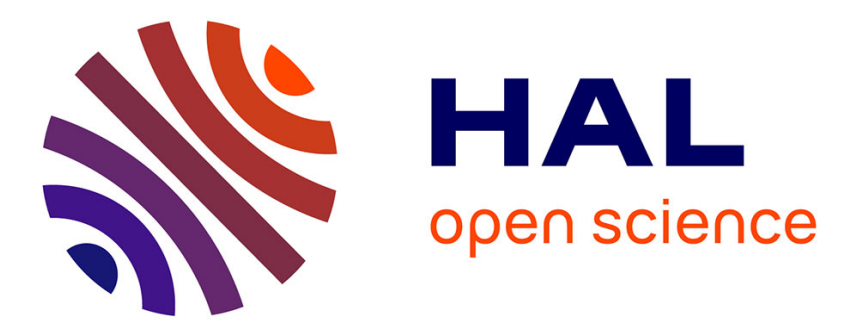

\title{
Zinc isotopic fractionation between aqueous fluids and silicate magmas: an experimental study
}

Haihao Guo, Ying Xia, Fei Wu, Fang Huang

\section{To cite this version:}

Haihao Guo, Ying Xia, Fei Wu, Fang Huang. Zinc isotopic fractionation between aqueous fluids and silicate magmas: an experimental study. Geochimica et Cosmochimica Acta, 2021, 311, pp.226-237. 10.1016/j.gca.2021.06.028 . insu-03278845

\section{HAL Id: insu-03278845 \\ https://hal-insu.archives-ouvertes.fr/insu-03278845}

Submitted on 6 Jul 2021

HAL is a multi-disciplinary open access archive for the deposit and dissemination of scientific research documents, whether they are published or not. The documents may come from teaching and research institutions in France or abroad, or from public or private research centers.
L'archive ouverte pluridisciplinaire HAL, est destinée au dépôt et à la diffusion de documents scientifiques de niveau recherche, publiés ou non, émanant des établissements d'enseignement et de recherche français ou étrangers, des laboratoires publics ou privés. 


\section{Journal Pre-proofs}

Zinc isotopic fractionation between aqueous fluids and silicate magmas: an experimental study

Haihao Guo, Ying Xia, Fei Wu, Fang Huang

PII: S0016-7037(21)00377-X

DOI: https://doi.org/10.1016/j.gca.2021.06.028

Reference:

GCA 12271

To appear in:

Geochimica et Cosmochimica Acta

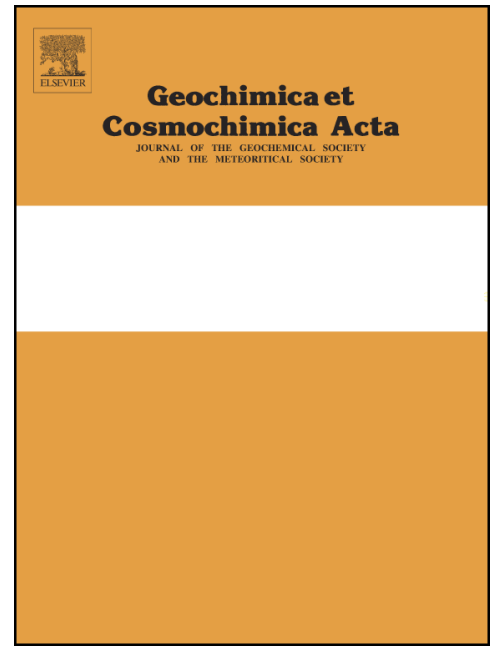

Received Date: $\quad 22$ January 2021

Revised Date: $\quad 18$ June 2021

Accepted Date: $\quad 20$ June 2021

Please cite this article as: Guo, H., Xia, Y., Wu, F., Huang, F., Zinc isotopic fractionation between aqueous fluids and silicate magmas: an experimental study, Geochimica et Cosmochimica Acta (2021), doi: https://doi.org/ 10.1016/j.gca.2021.06.028

This is a PDF file of an article that has undergone enhancements after acceptance, such as the addition of a cover page and metadata, and formatting for readability, but it is not yet the definitive version of record. This version will undergo additional copyediting, typesetting and review before it is published in its final form, but we are providing this version to give early visibility of the article. Please note that, during the production process, errors may be discovered which could affect the content, and all legal disclaimers that apply to the journal pertain.

(C) 2021 Elsevier Ltd. All rights reserved. 


\section{Zinc isotopic fractionation between aqueous fluids and}

\section{silicate magmas: an experimental study}

Haihao Guo ${ }^{\mathrm{a}, \mathrm{b}^{*}}$, Ying $\mathrm{Xia}^{\mathrm{c}}$, Fei Wu${ }^{\mathrm{d}}$, Fang Huang, ${ }^{\mathrm{c}, \mathrm{e}^{*}}$

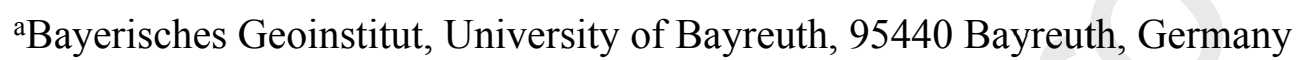

'ISTO, UMR 7327 CNRS-Université d'Orléans-BRGM, 45071 Orléans, France

${ }^{c}$ CAS Key Laboratory of Crust-Mantle Materials and Environments, School of Earth and Space Sciences, University of Science and Technology of China, 230026 Hefei, China

${ }^{\mathrm{d} S c h o o l}$ of Earth Sciences, State Key Laboratory of Geological Processes and Mineral Resources, China University of Geosciences, Wuhan 430074, China

${ }^{\mathrm{e} C A S}$ Center for Excellence in Comparative Planetology, China

*Corresponding authors, E-mail addresses: haihao.guo@cnrs-orleans.fr (H-H. Guo), fhuang@ustc.edu.cn (F. Huang). 


\section{Abstract}

Fluids in magmas play a key role in magma differentiation and transportation of economic metals for ore deposits. As a chalcophile and incompatible element, zinc and its isotopes have been increasingly applied to study the magmatic-hydrothermal processes. However, zinc isotopic fractionation between aqueous fluids and magmas has not been well constrained. Here we experimentally determined equilibrium fractionation factors of $\mathrm{Zn}$ isotopes between aqueous fluids and silicate magmas $\left(\Delta^{66} \mathrm{Zn}_{\text {fluid-magma }}=\delta^{66} \mathrm{Zn}_{\text {fluid }}-\delta^{66} \mathrm{Zn}_{\text {magma }}\right.$ ). The results reveal that aqueous fluids are isotopically heavier than the coexisting silicate magmas. No correlation between $\Delta^{66} \mathrm{Zn}_{\text {fluid-magma }}$ and temperature or chlorine contents in fluids is observed under our experimental conditions. Instead, $\Delta^{66} \mathrm{Zn}_{\text {fluid-magma }}$ is negatively corresponded with $\mathrm{NBO} / \mathrm{T}$ of the melt (the ratio of non-bridge oxygen and tetrahedron ions), and positively correlated with the molar ratio of $\mathrm{Al} /(0.5 \mathrm{~K}+\mathrm{Ca}+\mathrm{Fe})$ in the bulk magmas, suggesting the controlling of silicate composition on $\mathrm{Zn}$ isotope fractionation. Our data therefore indicate that the isotopically heavier $\mathrm{Zn}$ in the fluids exsolved from magmas may account for the higher $\delta^{66} \mathrm{Zn}$ of pegmatites and high-silica granitic rocks. Moreover, involvement of magmatic fluids can explain the highly variable and remarkably heavier $\mathrm{Zn}$ isotopic signatures of fumaroles, thermal spring waters, and seafloor hydrothermal fluids compared to the igneous rocks. This study provides information that can be used to guide research using $\mathrm{Zn}$ isotopes to trace fluid activity and magmatism. 


\section{INTRODUCTION}

The emitted gases or aerosols by active volcanoes suggest that high temperature fluids scavenge and transport significant amounts of volatiles and metals from magma (e.g., Zelenski et al., 2013; Menard et al., 2014; Zelenski et al., 2014). These fluids could transport fundamental components (e.g., sulfur and metals) from magma chambers to form magmatic hydrothermal ore deposits (e.g., Hedenquist and Lowenstern, 1994; Williams-Jones and Heinrich, 2005). Zinc is a strongly chalcophile and moderately incompatible element with five stable isotopes, i.e., ${ }^{64} \mathrm{Zn}(49.19 \%)$, ${ }^{66} \mathrm{Zn}(27.79 \%),{ }^{67} \mathrm{Zn}(4.04 \%),{ }^{68} \mathrm{Zn}(18.39 \%)$, and ${ }^{70} \mathrm{Zn}(0.60 \%)$. Zinc and its isotopes can be tracers in the magmatic hydrothermal systems because it is widely present in igneous rocks and hydrothermal fluids, such as fumarolic gases, condensates, and thermal springs. Zinc is a mono-valent $(+2)$ metal, and thus its isotopic behavior is not directly affected by redox reactions (Albarède, 2004).

Zinc is a trace element in the continental crust and mantle (crust: $\sim 72 \mathrm{ppm}$; mantle: 55 ppm; McDonough and Sun, 1995; Rudnick and Gao, 2003). Previous studies suggested that magmatic differentiation only generates limited $\mathrm{Zn}$ isotope fractionation in volcanic rocks (e.g., Chen et al., 2013; Huang et al., 2018). In contrast, large Zn variations ( $\delta^{66} \mathrm{Zn}$ values range from $0.12 \%$ to $0.88 \%$ ) have been reported in felsic rocks (e.g., Telus et al., 2012; Huang et al., 2018; Xu et al., 2019). Proterozoic to Cenozoic pegmatites studied by Telus et al. (2012) display some of the heaviest $\mathrm{Zn}$ isotope composition among all the published data of igneous rocks, with $\delta^{66} \mathrm{Zn}$ values of $+0.53 \%$ o to $+0.88 \%$. These $\mathrm{Zn}$ isotopic variations in the high-silica granite and pegmatite may be associated with the aqueous fluids exsolved from felsic magmas, but $\mathrm{Zn}$ isotope fractionation between fluids and magma remains unclear. 
Previous studies also demonstrated that $\mathrm{Zn}$ isotope geochemistry has the potential to explore hydrothermal ore genesis processes (e.g., Kelley et al., 2009; Pašava et al., 2014) and trace Zn transport in hydrothermal systems (e.g., John et al., 2008; Gagnevin et al., 2012; Chen et al., 2014). Recent studies of sphalerite showed that kinetic fractionation may result in precipitation of low $\delta^{66} \mathrm{Zn}$ sphalerite in the early fluid evolutions (Wilkinson et al., 2005; Kelley et al., 2009). A study on submarine hydrothermal vents also suggested that subsurface $\mathrm{Zn}$ sulfide precipitation prefers light $\mathrm{Zn}$ isotopes and can cause variations in $\delta^{66} \mathrm{Zn}$ of hydrothermal fluids (John et al., 2008). Chen et al. (2014) suggested that heavier $\mathrm{Zn}$ isotope favors the fluid phase during high temperature water-rock reactions. Fujii et al. $(2011,2014)$ and Ducher et al. (2016, 2018) calculated the fractionation factors of $\mathrm{Zn}$ compounds in aqueous fluids. However, the causes for large variations in $\mathrm{Zn}$ isotopic compositions of fumaroles from volcanic studies (Toutain et al., 2008; Chiaradia et al., 2018) and sphalerite in hydrothermal deposits (Mathur and Wang, 2019) are still controversial.

Equilibrium isotope fractionation factors of $\mathrm{Zn}$ between aqueous fluids and silicate magmas are essential for understanding $\mathrm{Zn}$ isotopic behaviors in magma degassing and water-rock reactions. Here we experimentally determined the $\mathrm{Zn}$ isotope equilibrium fractionation factors between fluids and mafic to felsic magmas (i.e., basalt, andesite, dacite, rhyolite dacite, rhyolite and haplogranite) at 700 to $900{ }^{\circ} \mathrm{C}$ and $2 \mathrm{kbar}$. These data provide $\mathrm{Zn}$ isotope fractionation factors between silicate magma and aqueous fluids to understand $\mathrm{Zn}$ isotopic behaviors in magmatic hydrothermal processes. 


\section{METHOD}

\subsection{Staring materials}

Six glasses or rock powders were used as starting materials, and their compositions are given in Table 1. Basalt is a grinded natural rock from Two Buttes, southeastern Colorado, which was also used in Guo and Audetat (2017). Andesite is the natural andesite (AGV-1) and rhyolite is the natural rhyolite (RGM-1) reference materials from the USGS. Dacite and rhyolite dacite are synthetized silicate glasses with compositions similar to the volcanic rocks (Masotta et al., 2016). The other felsic material is a haplogranite of 1 kbar eutectic melt composition.

\subsection{High temperature and pressure experiments}

All the experiments were conducted in Au capsules with $5.0 \mathrm{~mm}$ O.D. (outer diameter), $4.6 \mathrm{~mm}$ I.D. (inner diameter) and $20 \mathrm{~mm}$ length. Each glass or rock powder was loaded into capsules with a similar amount of solution $(\sim 100 \mathrm{mg})$ containing $\sim 1000$ ppm $\mathrm{Zn}$ as $\mathrm{ZnCl}_{2}$ dissolved in water and $1.75 \mathrm{wt} \%$ to $7 \mathrm{wt} \% \mathrm{HCl}$. Capsules were then welded closed with a pulsed arc welder and annealed at $125^{\circ} \mathrm{C}$ in an oven for a few hours, and finally weighed to check for the loss of weight. The capsules that showed no obvious weight loss $(<0.0001 \mathrm{~g})$ were then loaded into vertical rapid-quench cold-seal pressure vessels made of Inconel 713LC superalloy in a setup similar to that described in Matthews et al. (2003), using water as the pressure medium. Temperatures were measured with NiCr-Ni (K-type) thermocouples in an external borehole of the vessels. Uncertainties in the temperature and pressure readings are $\pm 5^{\circ} \mathrm{C}$ and \pm 30 bar (or better), respectively. Oxygen fugacity was not specifically controlled in the vessels, but by the reaction of water with the autoclave material, it was $0.5-1 \log$ unit above $\mathrm{Ni}-\mathrm{NiO}$ buffer. 
All the experiments were run at 700 to $900{ }^{\circ} \mathrm{C}$ and $2 \mathrm{kbar}$ with durations ranging from

7 days to 15 days. The samples were quenched by dropping the external magnet to make the sample fall into the water-cooled zone within a few seconds.

The recovered capsules were weighted again to check the potential leaks during the experiments. The capsules without clear weight changes were then well cleaned, cooled by liquid- $\mathrm{N}_{2}$ and punctured with a steel needle. The solution was withdrawn as much as possible with a micropipette. The capsules were opened, and boiled in deionized water for 30 minutes. After that, the samples were rinsed several times with distilled water. All of the solutions obtained during these operations were added to the solution withdrawn from the capsule. This treatment is similar to Keppler and Wyllie (1991) which is to re-dissolve material precipitated from the fluid during quenching. The residue glasses and rocks were ground and boiled in deionized water for 30 minutes to remove the fluid bubbles inside. The powders were then leached by deionized water a few times and dried in ovens for next steps. The solution samples collected in the whole process were evaporated to dryness on a hot plate for next analyses.

\subsection{Analytical methods}

Backscattered electron (BSE) images of polished sections through the recovered solid samples were taken on a Zeiss Gemini 1530 field emission scanning electron microscope (FE-SEM) at Bayerisches Geoinstitut, University of Bayreuth. The running conditions were under an accelerating voltage of $20 \mathrm{kV}$, a working distance of $\sim 14 \mathrm{~mm}$ and an aperture of $60 \mu \mathrm{m}$. An energy-dispersive spectrometer (EDS) was used to identify mineral phases in the run products.

Both the sample powders and dry fluid residues were dissolved in a combination 
of double-distilled, concentrated $\mathrm{HF}-\mathrm{HNO}_{3}-\mathrm{HCl}$ in pre-cleaned screw-top Teflon beaker. After fully digestion and evaporation of the acid solution, the residues were refluxed with $1 \mathrm{~mL}$ concentrated $\mathrm{HCl}$. A small fraction of each sample solution was diluted in $2 \% \mathrm{HNO}_{3}$ at appropriate levels for element-composition analyses using a Perkin-Elmer ELAN DCR-II inductively coupled plasma source mass spectrometer (ICP-MS) at the CAS Key Laboratory of Crust-Mantle Materials and Environments, University of Science and Technology of China, Hefei (USTC). The detailed procedures were described in Hou and Wang (2007).

Zinc isotopic compositions of run products were analyzed at the USTC using the established procedures of Chen et al. (2016). The chemical purification of $\mathrm{Zn}$ was achieved by cation exchange chromatography with Bio-Rad AG-MP-1 anion resin in a $0.5 \mathrm{~N} \mathrm{HNO}_{3}$ media. The whole purification procedure was repeated twice to ensure efficiently purification of $\mathrm{Zn}$ from interference cations. The $\mathrm{Zn}$ recoveries through column chemistry, based on analyses of $\mathrm{Zn}$ concentration in the elution collected before and after the $\mathrm{Zn}$ cut, were $>99 \%$. Total procedural blanks were $<10 \mathrm{ng}$, negligible relative to $\sim 2 \mu \mathrm{g} \mathrm{Zn}$ loaded onto columns.

Zinc isotope ratios were measured using a Thermo-Fisher Neptune Plus MC-ICP-MS at a low resolution at the USTC. The purified samples were dissolved in a $2 \% \mathrm{HNO}_{3}$ solution and introduced into the instrument using an ESI PFA microflow nebulizer with an uptake rate of $50 \mu \mathrm{L} / \mathrm{min}$. $\mathrm{Zn}$ isotope ratios are reported in standard $\delta$-notation in per mil relative to JMC Lyon $\mathrm{Zn}$ standard 3-0749 L: $\delta^{\mathrm{X}} \mathrm{Zn}$ $=\left[\left({ }^{\mathrm{X} Z n} /{ }^{64} \mathrm{Zn}\right)_{\text {sample }} /\left({ }^{\mathrm{X}} \mathrm{Zn} /{ }^{64} \mathrm{Zn}\right)_{\mathrm{JMC} \text { Lyon }}-1\right] \times 1000 \%$, where $\mathrm{X}=66$, or 68 . The long term external precisions are better than $0.05 \%$ (2SD) for $\delta^{66} \mathrm{Zn}$ and $0.08 \%$ (2SD) for $\delta^{68} \mathrm{Zn}$. The $\delta^{66} \mathrm{Zn}$ of USGS reference standards obtained in this study agree well within error 
with previously published values (Chen et al., 2016). The results for replicate analyses also assure the accuracy and precision of our data.

\section{RESULTS}

The experimental conditions and $\mathrm{Zn}$ isotopic results of run products are shown in Table 2. The chemical compositions of run products are summarized in Table 3 . The quenched experimental products contain a quenched fluid phase (fluid inclusions or cavities), and residue silicate magmas (quenched silicate melts and/or minerals) (Fig. 1). The mineral assemblages in experimental products are clinopyroxene, plagioclase, phlogopite, magnetite, and ilmenite (Fig. 1). The bulk fluid phases and quenched solid residue phases (quenched magmas) were analyzed for elemental and isotopic compositions to represent the fluids and magmas, respectively.

For $\mathrm{Zn}$ isotopes, the fluid phases are enriched in heavy isotopes relative to the coexisting silicate magma phases (Fig. 2), as evidenced by the data points above the 1:1 line $\left(\delta^{66} \mathrm{Zn}_{\text {fluid }}=\delta^{66} \mathrm{Zn}_{\text {magma }}\right)$. All the analytical data for fluid and magma products are plotted on the 1:2 line on the three-isotope diagram ( $\delta^{68} \mathrm{Zn}$ vs. $\left.\delta^{66} \mathrm{Zn}\right)$. $\mathrm{Zn}$ isotopic fractionation values between fluids and magmas $\left(\Delta^{66} \mathrm{Zn}_{\text {fluid-magma }}=\delta^{66} \mathrm{Zn}_{\text {fluid }}-\delta^{66} \mathrm{Zn}\right.$ magma) exhibit similar values for the same magma types (i.e., basalt, andesite, dacite, rhyolite dacite, rhyolite and haplogranite), demonstrated by the parallel trends of the same magma types to the 1:1 line (Fig. 2). Zn isotope fractionation values between fluids and magmas are identical $\left(\Delta^{66} \mathrm{Zn}_{\text {fluid-magma }}=0.81 \pm 0.06\right.$ to $0.88 \pm 0.05 \%$ o $)$ for the haplogranite experiments using $3.5 \mathrm{wt} \% \mathrm{Cl}$ bearing fluids with durations of 7 days to 15 days (Fig. 3a). For the rhyolite experiments with 1.75 to $7 \mathrm{wt} \% \mathrm{Cl}$ bearing fluids, $\Delta^{66} \mathrm{Zn}_{\text {fluid-magma }}$ also display consistent values, i.e., $0.36 \pm 0.05 \%$ o to $0.40 \pm 0.04 \%$ o (Fig. 3b). No $\mathrm{Zn}$ isotope variation is observed for the haplogranite experiments $(3.5 \mathrm{wt} . \% \mathrm{Cl}$ 
in fluid) under various experimental temperature from 700 to $900^{\circ} \mathrm{C}$, with $\Delta^{66} \mathrm{Zn}_{\text {fluid- }}$ magma vary from $0.81 \pm 0.06 \%$ to $0.88 \pm 0.05 \%$ (Fig. 3c). Overall, the experimental duration, fluid chlorinity, and temperature do not clearly affect the $\mathrm{Zn}$ isotope equilibrium fractionation between fluids and magmas under the experimental conditions in this study. However, $\Delta^{66} \mathrm{Zn}_{\text {fluid-magma }}$ shows a broad negative correlation with $\mathrm{NBO} / \mathrm{T}$ of the bulk magmas, ranging from $0.05 \pm 0.06 \%$ to $1.24 \pm 0.05 \%$ (Fig. 3d). Moreover, $\Delta^{66} \mathrm{Zn}_{\text {fluid-magma }}$ increases with increasing molar ratio of $\mathrm{Al} /(0.5 \mathrm{~K}+\mathrm{Ca}+\mathrm{Fe})$ in the bulk magmas from $0.05 \pm 0.06 \%$ to $1.24 \pm 0.05 \%$ (Fig. $3 \mathrm{e}$ ). $\Delta^{66} \mathrm{Zn}_{\text {fluid-magma }}$ was also plotted with other elemental ratio, such as molar ratio of $\mathrm{Al} /(0.5 \mathrm{~K}+\mathrm{Ca}+0.5 \mathrm{Na})$ (Fig. $3 \mathrm{f})$, but no clear corresponding correlation was observed (Fig. S2).

\section{DISCUSSION}

\subsection{Controlling factors for $\mathrm{Zn}$ isotope equilibrium fractionation}

Our experimental strategy was similar to the recent copper and barium isotope studies (Guo et al., 2020a; 2020b), which determined the equilibrated isotopic fractionation factors between aqueous fluids and quenched silicate magmas. Time series experiments obtained reproducible $\mathrm{Zn}$ isotopic fractionation factors (Fig. 3a), demonstrating that equilibrium was attained within our experimental durations. In comparison with other studies on stable isotope fractionation (e.g., Meyer et al., 2008; Guo et al., 2020a), our experimental durations are long enough to reach the isotopic exchange equilibrium.

Previous studies showed chloride concentrations in the fluids have remarkable effects on the partition coefficients of $\mathrm{Zn}$ between fluids and magmas (Urabe, 1987; 
Zajacz et al., 2008), i.e., $\mathrm{D}_{\mathrm{Zn} \text { _fluid-magma }}=\mathrm{C}_{\text {fluid }} / \mathrm{C}_{\text {magma }}$, where $\mathrm{C}_{\text {fluid }}$ is the $\mathrm{Zn}$ concentration in the fluid phase and $\mathrm{C}_{\text {magma }}$ is that in magma phase. Our results display similar trends on $\mathrm{D}_{\mathrm{Zn} \_ \text {fluid-magma }}$ increasing with increase of chloride concentration in the fluids (Fig. 4a). Increasing temperature can decrease the $\mathrm{D}_{Z_{\text {n_ fluid-magma }}}$ in the haplogranite and 3.5 wt $\% \mathrm{Cl}$ bearing fluids at $700-900{ }^{\circ} \mathrm{C}$ (Fig. 4b), consistent with results in a previous study (London et al., 1988). However, our experiments reveal that $\mathrm{Zn}$ isotope fractionation is not clearly related to temperature and fluid compositions but controlled by melt compositions (Fig. 3).

The consistent $\Delta^{66} \mathrm{Zn}_{\text {fluid-magma }}$ with different salinity fluids at various temperatures reflect the similar $\mathrm{Zn}$ speciation in the fluid phase. $\mathrm{Zn}-\mathrm{Cl}$ complexes of $\mathrm{ZnCl}_{4}{ }^{2-}$ and $\mathrm{ZnCl}_{3}{ }^{-}$may be stable in chloride-rich hydrothermal fluids at high temperature (e.g., Mei et al., 2015; Brugger et al., 2016). The overall positive $\Delta^{66} \mathrm{Zn}_{\text {fluid-magma }}$ indicate that heavy $\mathrm{Zn}$ isotopes are preferentially enriched into the $\mathrm{Zn}-\mathrm{Cl}$ complexes in the fluids, and light $\mathrm{Zn}$ isotopes are preferentially fractionated into the silicate magmas (melts and/or minerals). $\Delta^{66} \mathrm{Zn}_{\text {fluid-magma }}$ decreases with increasing $\mathrm{NBO} / \mathrm{T}$ in the melts, and increases with increasing $\mathrm{Al} /(0.5 \mathrm{~K}+\mathrm{Ca}+\mathrm{Fe})$ in magma components (Fig. 3e), indicating that the coordination environments of zinc in the silicates are the key factors for controlling its isotopic fractionation. As a trace element, Zn may substitute the K, Ca, and Fe cations because they are in the same period of the periodic table, and have comparable radiuses (Shannon, 1976). The silicate magmas with low NBO/T and high $\mathrm{Al} /(0.5 \mathrm{~K}+\mathrm{Ca}+\mathrm{Fe})$ molar ratios favor light $\mathrm{Zn}$ isotopes incorporating into their structures, resulting in increased $\Delta^{66} \mathrm{Zn}_{\text {fluid-magma }}$ values, and showing the sensitive effect of the compositions of silicate magmas. Although such observations are important and useful for understanding $\mathrm{Zn}$ isotope fractionation mechanism, the physics behind such observations are not clear and requires further investigation. 


\subsection{Implications for $\mathrm{Zn}$ isotope compositions in igneous rocks}

The felsic igneous rocks, especially high-silica granitic rocks $\left(\mathrm{SiO}_{2}>70 \%\right)$, exhibit large $\mathrm{Zn}$ isotopic variations (Fig. 5). These high silica granites, leucogranites, or pegmatites are remarkable enriched in heavy $\mathrm{Zn}$ isotopes relative to the mafic igneous rocks (e.g., Telus et al., 2012; Doucet et al., 2018; Xu et al., 2019; Wang et al., 2020). The high $\delta^{66} \mathrm{Zn}$ signature of the high silica rocks has been ascribed to the isotope fractionation during partial melting, magma differentiation and/or fluid exsolution (e.g., Telus et al., 2012; Xu et al., 2019; Wang et al., 2020). Mantle peridotites and komatiites have indistinguishable Zn isotopic compositions (Wang et al., 2017; Huang et al., 2018; Sossi et al., 2018), suggesting that partial melting only induces small $\mathrm{Zn}$ isotope fractionation, as shown by the variations from the ultramafic to mafic igneous rocks from both tholeiitic, intraplate systems and calc-alkaline systems (Fig. 5). Chen et al. (2013) found that $\mathrm{Zn}$ isotope fractionation during magma differentiation is $<0.1 \%$ based on the study of cogenetic igneous rocks from the Kilauea Iki lava lake, Hawaii and Hekla, Iceland. Rocks from the Kamchatka-Aleutian arcs (Huang et al., 2018) and bimodal volcanic rocks from Hailar Basin (Xia et al., 2017) only show slight Zn isotopic fractionation in magmatic systems. The magnitude of $\mathrm{Zn}$ isotope fractionation during fractional crystallization and partial melting are too small to explain the remarkable $\mathrm{Zn}$ isotope variations in high-silica granitic rocks.

Theoretical calculations have been conducted to estimate the $\mathrm{Zn}$ isotope fractionation between aqueous $\mathrm{Zn}$ species and solid $\mathrm{Zn}$ phase $\left(\Delta^{66} \mathrm{Zn}_{\text {fluid-solid }}\right)$ (Fujii et al., 2014; Ducher et al., 2016; 2018). These studies implied that the fluid phase is enriched in $\mathrm{Zn}$ ( $\mathrm{Zn}-\mathrm{Cl}$ phase) and has lighter $\mathrm{Zn}$ isotope composition relative to zincite ( $\mathrm{ZnO})$. This mineral is considered to be an analogue to the $\mathrm{Zn}$ coordination environment 
in melt. Thus, the high-silica granitic rocks with heavier $\mathrm{Zn}$ isotope compositions were previously attributed to fluid removal of isotopically light $\mathrm{Zn}$ from the high silica magma and resulting in the heavy $\mathrm{Zn}$ compositions to the residue silicate rocks (e.g., $\mathrm{Xu}$ et al., 2019). However, our experiments reveal that fluids favor heavy $\mathrm{Zn}$ isotopes over the coexisting silicate magmas, with $\Delta^{66} \mathrm{Zn}_{\text {fluid-magma }}$ as high as $\sim 0.4 \%$ o to $\sim 0.8 \%$ o for high silica rocks (Fig. 3). The discrepancy between our experimentally determined $\Delta^{66} \mathrm{Zn}_{\text {fluid-magma }}$ and that speculated from theoretical calculation (Fujii et al., 2014; Ducher et al., 2016; 2018) may be due to that the $\mathrm{Zn}$ is differently coordinated in zincite and silicate melt. In addition, our experimental results indicate that the heavy $\mathrm{Zn}$ isotope composition observed in high silica rocks cannot be explained by the fluid removal process. On the contrary, the fluid formed during exsolution processes is more likely enriched in heavy $\mathrm{Zn}$ isotopes compared to the residue silicates. Accumulation and transportation of these fluids and reaction with wall rock afterwards might cause the heavy $\mathrm{Zn}$ isotope compositions of the high silica rocks.

The exsolved magma commonly experiences volatile (mainly water) saturation as it ascends and cools (Edmonds and Woods, 2018). Volatile-rich fluids are then exsolved from the magma and sequester fluid mobile elements from the magma phase to the fluid phase. These processes often happen in the highly evolved silicate magmas (high silica), as evidenced by the coexisting fluid and melt inclusions in the quartz crystals (Audétat and Pettke, 2003; Zajacz et al., 2008). The aqueous fluids that exsolved from magmatic intrusions have relatively low chlorinity $\left(2-10 \mathrm{wt} . \% \mathrm{NaCl}_{\text {equiv }}\right)$ compared to the highdensity brine (e.g., Audétat and Pettke, 2003; Audétat et al., 2008). Natural aqueous fluids from melt exsolution is enriched $\mathrm{Zn}$ by forming $\mathrm{Zn}$-chlorine complexes, such as $\mathrm{ZnCl}_{4}{ }^{2-}$ and $\mathrm{ZnCl}_{3}{ }^{-}$(e.g., Mei et al., 2015; Brugger et al., 2016). Assuming that the fluid phase is continuously removed from the magma through fractional distillation, then 
$\delta^{66} \mathrm{Zn}$ of residue magmas and the fluids during this process can be modelled by the following Rayleigh fractionation equations:

$$
\begin{aligned}
& \delta^{66} Z n_{\text {magma }}=\left(\delta^{66} Z n_{\text {initial }}+1000\right) f^{(\alpha-1)}-1000 \\
& \delta^{66} Z n_{\text {fluid }}=\left(\delta^{66} Z n_{\text {initial }}+1000\right)\left(f^{\alpha}-1\right) /(f-1)-1000
\end{aligned}
$$

Where $\delta^{66} \mathrm{Zn}_{\text {initial }}$ refers to the $\mathrm{Zn}$ isotopic composition of the initial volatile-rich magmas and $f$ is the fraction of $\mathrm{Zn}$ in residual magmas, $\alpha$ is the $\mathrm{Zn}$ isotope fractionation factor between the fluid and magma, with the relationship $\alpha \approx 1+\Delta^{66} \mathrm{Zn}_{\text {fluid-magma. The }}$ model is conducted with $\Delta^{66} \mathrm{Zn}_{\text {fluid-magma }}=0.2,0.4$, and $0.8 \%$, which are the ranges of the experimental results. The model shows that fluid exsolution (commonly from very low content to up to $10 \mathrm{wt}$.\%) can produce the fluids with similarly heavy $\mathrm{Zn}$ isotopic compositions compared to the high silica granitic rocks (Fig. 5).

Magmatic volatiles physically separate from the parent magmas and form discrete liquid pulses that both form new fractures, and follow existing, fractures into the brittle rocks overlying the batholithic system (Tosdal and Richards, 2001). The narrow conduits could be an accumulation zone for the volatiles and metals rich fluids, because the dense magma forms a downward return flow to the large magma batholith. Fluid pressure can further cause fractures in the cover rocks, and fault zones provide highpermeable pathways for fluid and magma ascending. The fractures may first be opened and propagated by the fluid pressure, and later filled by more viscous magma, forming cylinder dikes of high silica granite or pegmatite (Burnham, 1997; Carrigan et al., 1992; Rubin, 1995). The felsic rocks formed in the volcanic conduits are likely to inherit the high $\delta^{66} \mathrm{Zn}$ features of magmatic fluids, because the environment is enriched in fluids containing substantial abundance of $\mathrm{Zn}$. Pegmatites are usually formed at the roofs of 
the intrusions where aqueous fluids coexist with silicate melts, which is evidenced by the common occurrence of miarolitic cavities (e.g., Thomas et al., 2009; London et al.,2012). The high silica rocks are altered by the magmatic fluids enriched in heavy Zn isotopes, and should inherit the heavy $\mathrm{Zn}$ isotopic compositions of the fluids.

\subsection{Implications for $\mathrm{Zn}$ isotopes in hydrothermal systems}

Zinc is a moderately volatile element that behaves similarly to the volatiles (e.g., $\mathrm{S}$ and $\mathrm{Cl}$ ) and transition metals (e.g., As, $\mathrm{Sb}$, and $\mathrm{Tl}$ ) during magma degassing (Symonds et al., 1987; Taran et al., 1995; Guo and Audétat, 2017). Thus, magmatic fluids, which contain considerable amounts of $\mathrm{Zn}$, should be the dominant $\mathrm{Zn}$ source for the fumarole gases. Zinc isotopic variations in the fumarolic gases may be due to the isotopic fractionation during the degassing processes. Since magma differentiation (segregation of crystals in the magma chambers) induces limited $\mathrm{Zn}$ fractionation, the $\mathrm{Zn}$ isotopic signatures of the magmas with fumarolic components are assumed to be homogeneous. The degree of $\mathrm{Zn}$ incorporation into the fumarolic gases is defined in terms of relative enrichment factors (EF) (Lepel et al., 1978):

$$
\mathrm{EF}=\left(\mathrm{X}_{\mathrm{g}} / \mathrm{R}_{\mathrm{g}}\right) /\left(\mathrm{X}_{\mathrm{m}} / \mathrm{R}_{\mathrm{m}}\right)
$$

For an element $\mathrm{X}, \mathrm{g}$ and $\mathrm{m}$ refer to the gas sample and the rock, respectively, and $\mathrm{R}$ is a fluid-immobile reference element with respect to volcanic fluids. Since Ti was highly immobile in the volcanic fluids, Ti was usually chosen as the reference element. The enrichment factors of $\mathrm{Zn}$ range from 120 to 1041 obtained from the analyses of high temperature fumarolic gases/aerosols and igneous rocks from arc volcanoes such as Tolbachik (Zelenski et al., 2014), Erta Ale (Zelenski et al., 2013), Lascar (Menard et al., 2014) and Etna (Aiuppa et al., 2003). The high Zn concentration in fumarolic 
components suggests that magma degassing could enrich $\mathrm{Zn}$ in the fumarolic gases, which could also fractionate $\mathrm{Zn}$ isotopes between the magmas and the fumarole gases.

The fumarolic gases (Toutain et al., 2008; Chen et al., 2014; Chiaradia et al., 2018), thermal spring waters of La Soufrière volcano (Chen et al., 2014), hydrothermal alteration zones around the crater fumaroles (Vulcano) (Chiaradia et al., 2018), and sea floor hydrothermal vents (John et al., 2008) show large variations but generally high $\delta^{66} \mathrm{Zn}$ compared to the mafic to intermediate silicate rocks (Fig. 5). This is broadly consistent with our experimental results that magma-derived fluids preferentially scavenge heavy $\mathrm{Zn}$ isotopes from magmas. The large variations and low $\delta^{66} \mathrm{Zn}$ values are probably due to the water rock reaction, mixing with water from other sources, and/or kinetic fractionation during sphalerite precipitation (Wilkinson et al., 2005; Chen et al., 2014; Chiaradia et al., 2018).

Toutain et al. (2008) firstly reported that $\delta^{66} \mathrm{Zn}$ in the fumarolic gases of Merapi volcano (Indonesia) are ranging from $+0.05 \%$ to $+0.85 \%$, generally higher than the $\delta^{66} \mathrm{Zn}$ of homogeneous andesitic rock samples with a mean value of $+0.24 \%$. The condensate samples from the gases display very high $\delta^{66} \mathrm{Zn}$ from $+1.48 \%$ to $+1.68 \%$. They proposed that the condensates are enriched in the heavier isotopes from the gasses and thus condensation decreases gaseous $\mathrm{Zn}$ concentrations enriched in light $\mathrm{Zn}$ isotopes. Chen et al. (2014) also reported that fumaroles from La Soufrière volcano, on Guadeloupe Island (French West Indies) have similar or slightly higher $\delta^{66} \mathrm{Zn}(+0.21 \%$ o to $+0.35 \%$ ) compared to the local bedrock fresh andesite $(+0.21 \%$ ), and thermal springs are enriched in heavy $\mathrm{Zn}$ isotopes compared to the host rocks (Fig. 5). Although $\mathrm{Zn}$ stable isotope fractionation may also happen during the hydrothermal reactions at 
high temperatures, these studies imply that the initial fluids derived from magma degassing have higher $\delta^{66} \mathrm{Zn}$ than their host magma reservoirs.

The $\mathrm{Zn}$ isotope compositions ( $\delta^{66} \mathrm{Zn}$ ranges from $-0.3 \%$ to $+0.2 \%$ ) of Vulcano fumaroles are overall lighter than these of fumaroles from Merapi and La Soufrière (Chiaradia et al., 2018). A mixture of a hydrothermal endmember with low $\delta^{66} \mathrm{Zn}$ and a magmatic endmember with high $\delta^{66} \mathrm{Zn}$ are suggested to account for the trend (Chiaradia et al., 2018). Chiaradia et al. (2018) also found that the hydrothermal alteration zones around the fumarole vents have significantly high $\delta^{66} \mathrm{Zn}(0.3-1.6 \%)$, probably due to that the initial fumaroles are enriched in heavy $\mathrm{Zn}$ isotopes. Our experimental results are consistent with the volcanic observations that magma-derived fluids or gases are characterized by high $\delta^{66} \mathrm{Zn}$ than their host magma reservoirs. $\mathrm{Zn}$ isotopic fractionation during magma degassing could be a novel tool to constrain the hydrothermal processes in the magmatic differentiation, volcanic eruption, and element precipitation during water-rock reactions.

Except the volcanic systems, both high and low $\delta^{66} \mathrm{Zn}$ have been discovered in hydrothermal deposits (Gagnevin et al., 2012; Mathur and Wang, 2019). These anomalous $\mathrm{Zn}$ isotope ratios have been widely explained by precipitation of isotopically light sphalerite ( $\mathrm{Zn}$ sulfide) in the early stage during kinetic fractionation from hydrothermal fluids (Wilkinson et al., 2005; John et al., 2008; Kelley et al., 2009). However, the heavy $\delta^{66} \mathrm{Zn}$ fluids derived from magmas will become even heavier in $\mathrm{Zn}$ isotopes after the $\mathrm{Zn}$ isotopically light sulfide precipitation, which will be recorded by the subsequent sulfides at various stages. The large $\mathrm{Zn}$ isotope fractionation may be used to detect new deposits (Gagnevin et al., 2012), trace hydrothermal fluid sources (Pašava et al., 2014), or to identify the different mineral deposit stages (Wilkinson et 
al., 2005; Mathur and Wang, 2019). The experimental results and the observed high $\delta^{66} \mathrm{Zn}$ in the hydrothermal systems suggest that the magma generated fluids could be an important source of high $\delta^{66} \mathrm{Zn}$, which could contribute to global $\mathrm{Zn}$ cycles though interactions with groundwater, rivers, and atmosphere. The contribution of hydrothermal systems should be taken account when studying the global oceanic budget of $\mathrm{Zn}$ using $\mathrm{Zn}$ isotope data.

\section{CONCLUSIONS}

This study provides the first experimental study on $\mathrm{Zn}$ isotope equilibrium fractionation between aqueous fluids and silicate magmas at magmatic-hydrothermal conditions. In this study, chloride bearing fluids and silicates were equilibrated at conditions relevant to the coexistence of hydrothermal fluids and silicate magmas. Experiments involving fluids of different salinity, temperature, and rock composition resulted in a wide range of $\Delta^{66} \mathrm{Zn}_{\text {fluid-magma }}$ from $0.05 \pm 0.06 \%$ up to $1.24 \pm 0.05 \%$. The magnitude of $\mathrm{Zn}$ isotopic fractionation between fluid and magma is primarily depended on the magma compositions. While $\mathrm{Zn}$ species in aqueous fluids remain constant within a normal range of salinity and P-T conditions, the fractionation may be controlled by the $\mathrm{Zn}$ substitution mechanism in the melt structure.

Our data can be used to interpret the evaluated $\delta^{66} \mathrm{Zn}$ values of high-silica granitic rocks that involve the $\mathrm{Zn}$ in magmatic fluids. The $\mathrm{Zn}$ isotopic composition detected in samples derived from hydrothermal systems are broadly consistent with our experimental results. The heavy $\mathrm{Zn}$ isotopic signatures of magma-derived fluids can be observed in the fumarole samples, thermal springs or hydrothermal vents. $\mathrm{Zn}$ isotopes in hot hydrothermal fluids can be also affected by the rapid precipitation of sulfide segregation in isotopically light $\mathrm{Zn}$ isotopes. By deciphering the geochemical processes 
that affect $\mathrm{Zn}$ isotopic behaviors in the hydrothermal systems, our study provides new data that can be applied to $\mathrm{Zn}$ isotope studies of fluid relevant geological processes.

\section{ACKNOWLEDGEMENTS}

This work is supported by National Key R\&D Program of China (2018YFA0702600), and the Open Research Fund of the State Key Laboratory of Ore Deposit Geochemistry of China (201805). Fei Wu is funded by the startup Grant from China University of Geosciences (Wuhan). We are grateful to Huimin Yu and Xingchao Zhang for their help on $\mathrm{Zn}$ isotope analyses, Lijuan $\mathrm{Xu}$ for discussions. Jon Wade and an anonymous reviewer, and Helen Williams are thanked for reviewing and improving the manuscript. 


\section{REFERENCE}

Aiuppa, A., Dongarrà, G., Valenza, M., Federico, C. and Pecoraino, G. (2003) Degassing of trace volatile metals during the 2001 eruption of Etna. Volcanism and the Earth's atmosphere, 41-54.

Albarède, F. (2004) The stable isotope geochemistry of copper and zinc. Rev. Mineral. Geochem. 55, 409-427.

Audétat, A. and Pettke, T. (2003) The magmatic-hydrothermal evolution of two barren granites: A melt and fluid inclusion study of the Rito del Medio and Canada Pinabete plutons in northern New Mexico (USA). Geochim. Cosmochim. Acta 67, 97-121.

Audétat, A., Pettke, T., Heinrich, C.A. and Bodnar, R.J. (2008) The Composition of Magmatic-Hydrothermal Fluids in Barren and Mineralized Intrusions. Econ. Geol. 103, 877-908.

Brugger, J., Liu, W., Etschmann, B., Mei, Y., Sherman, D.M. and Testemale, D. (2016) A review of the coordination chemistry of hydrothermal systems, or do coordination changes make ore deposits? Chem. Geol. 447, 219-253.

Burnham, C.W. (1979) Magmas and hydrothermal fluids, in: Barnes, H.L. (Ed.), Geochemistry of Hydrothermal Ore Deposits, John Wiley, New York, pp. 71-136.

Carrigan, C.R., Schubert, G. and Eichelberger, J.C. (1992) Thermal and dynamical regimes of single-and two-phase magmatic flow in dikes. Journal of Geophysical Research: Solid Earth 97, 17377-17392. 
Chen, H., Savage, P.S., Teng, F.-Z., Helz, R.T. and Moynier, F. (2013) Zinc isotope fractionation during magmatic differentiation and the isotopic composition of the bulk Earth. Earth Planet. Sci. Lett. 369-370, 34-42.

Chen, J.-B., Gaillardet, J., Dessert, C., Villemant, B., Louvat, P., Crispi, O., Birck, J.L. and Wang, Y.-N. (2014) Zn isotope compositions of the thermal spring waters of La Soufrière volcano, Guadeloupe Island. Geochim. Cosmochim. Acta 127, 6782.

Chen, S., Liu, Y., Hu, J., Zhang, Z., Hou, Z., Huang, F. and Yu, H. (2016) Zinc Isotopic Compositions of NIST SRM 683 and Whole-Rock Reference Materials. Geostand. Geoanal. Res. 40, 417-432.

Chiaradia, M., Pujol-Solà, N., Farré-de-Pablo, J., Aiuppa, A., Paonita, A., Rizzo, A.L. and Brusca, L. (2018) Geochemistry and isotope composition ( $\mathrm{Sr}, \mathrm{Pb}, \delta 66 \mathrm{Zn}$ ) of Vulcano fumaroles (Aeolian Islands, Italy). Chem. Geol. 493, 153-171.

Debret, B., Bouilhol, P., Pons, M.L. and Williams, H. (2018) Carbonate Transfer during the Onset of Slab Devolatilization: New Insights from Fe and Zn Stable Isotopes. J. Petrol. 59, 1145-1166.

Ducher, M., Blanchard, M. and Balan, E. (2016) Equilibrium zinc isotope fractionation in $\mathrm{Zn}$-bearing minerals from first-principles calculations. Chem. Geol. 443, 87-96.

Ducher, M., Blanchard, M. and Balan, E. (2018) Equilibrium isotopic fractionation between aqueous $\mathrm{Zn}$ and minerals from first-principles calculations. Chem. Geol. 483, 342-350.

Edmonds, M. and Woods, A.W. (2018) Exsolved volatiles in magma reservoirs. J. Volcanol. Geotherm. Res. 368, 13-30. 
Fujii, T., Moynier, F., Blichert-Toft, J. and Albarède, F. (2014) Density functional theory estimation of isotope fractionation of $\mathrm{Fe}, \mathrm{Ni}, \mathrm{Cu}$, and $\mathrm{Zn}$ among species relevant to geochemical and biological environments. Geochim. Cosmochim. Acta $140,553-576$.

Fujii, T., Moynier, F., Pons, M.-L. and Albarède, F. (2011) The origin of Zn isotope fractionation in sulfides. Geochim. Cosmochim. Acta 75, 7632-7643.

Gagnevin, D., Boyce, A.J., Barrie, C.D., Menuge, J.F. and Blakeman, R.J. (2012) Zn, Fe and $\mathrm{S}$ isotope fractionation in a large hydrothermal system. Geochim. Cosmochim. Acta 88, 183-198.

Guo, H. and Audétat, A. (2017) Transfer of volatiles and metals from mafic to felsic magmas in composite magma chambers: An experimental study. Geochim. Cosmochim. Acta 198, 360-378.

Guo, H., Xia, Y., Bai, R., Zhang, X. and Huang, F. (2020a) Experiments on Cu isotope fractionation between chlorine bearing fluid and silicate magma: implications for fluid exsolution and porphyry Cu deposits. National Science Review 7, 1319-1330.

Guo, H., Li, W.Y., Nan, X. and Huang, F. (2020b) Experimental evidence for light Ba isotopes favouring aqueous fluids over silicate melts. Geochemical Perspectives Letters 16, 6-11.

Hou, Z. and Wang, C. (2007) Determination of 35 trace elements in geological samples by inductively coupled plasma mass spectrometry. Journal of University of Science and Technology of China 37, 940-944.

Huang, J., Chen, S., Zhang, X.C. and Huang, F. (2018) Effects of Melt Percolation on Zn Isotope Heterogeneity in the Mantle: Constraints From Peridotite Massifs in 
Ivrea-Verbano Zone, Italian Alps. Journal of Geophysical Research: Solid Earth $123,2706-2722$.

John, S.G., Rouxel, O.J., Craddock, P.R., Engwall, A.M. and Boyle, E.A. (2008) Zinc stable isotopes in seafloor hydrothermal vent fluids and chimneys. Earth Planet. Sci. Lett. 269, 17-28.

Kelley, K., Wilkinson, J., Chapman, J., Crowther, H. and Weiss, D. (2009) Zinc isotopes in sphalerite from base metal deposits in the Red Dog district, Northern Alaska. Econ. Geol. 104, 767-773.

Keppler, H. and Wyllie, P.J. (1991) Partitioning of Cu, Sn, Mo, W, U, and Th between melt and aqueous fluid in the systems haplogranite- $\mathrm{H}_{2} \mathrm{O}-\mathrm{HCl}$ and haplogranite$\mathrm{H}_{2} \mathrm{O}-\mathrm{HF}$. Contrib. Mineral. Petrol. 109, 139-150.

Lepel, E., Stefansson, K. and Zoller, W. (1978) The enrichment of volatile elements in the atmosphere by volcanic activity: Augustine volcano 1976. J. Geophys. Res. [Oceans] 83, 6213-6220.

London, D., Hervig, R.L. and Morgan, G.B. (1988) Melt-vapor solubilities and elemental partitioning in peraluminous granite-pegmatite systems: experimental results with Macusani glass at $200 \mathrm{MPa}$. Contrib. Mineral. Petrol. 99, 360-373.

London, D., Morgan, G.B., Paul, K.A. and Guttery, B.M. (2012) Internal evolution of miarolitic granitic pegmatites at the Little Three mine, Ramona, California, USA. Can. Mineral. 50, 1025-1054.

Maréchal, C.N., Nicolas, E., Douchet, C. and Albarède, F. (2000) Abundance of zinc isotopes as a marine biogeochemical tracer. Geochem. Geophys. Geosyst. 1, 1015, doi:1010.1029/1999GC000029. 
Masotta, M., Keppler, H. and Chaudhari, A. (2016) Fluid-melt partitioning of sulfur in differentiated arc magmas and the sulfur yield of explosive volcanic eruptions. Geochim. Cosmochim. Acta 176, 26-43.

Mathur, R. and Wang, D. (2019) Transition Metal Isotopes Applied to Exploration Geochemistry: Insights from $\mathrm{Fe}, \mathrm{Cu}$, and $\mathrm{Zn}$, in: Decrée, S., Robb, L. (Eds.), Ore Deposits: Origin, Exploration, Exploitation. John Wiley \& Sons, Inc., Hoboken, NJ, USA., pp. 163-183.

Matthews, W., Linnen, R.L. and Guo, Q. (2003) A filler-rod technique for controlling redox conditions in cold-seal pressure vessels. Am. Mineral. 88, 701-707.

Mei, Y., Sherman, D.M., Liu, W., Etschmann, B., Testemale, D. and Brugger, J. (2015) Zinc complexation in chloride-rich hydrothermal fluids $\left(25-600{ }^{\circ} \mathrm{C}\right)$ : A thermodynamic model derived from ab initio molecular dynamics. Geochim. Cosmochim. Acta 150, 265-284.

Menard, G., Moune, S., Vlastelic, I., Aguilera, F., Valade, S., Bontemps, M. and Gonzalez, R. (2014) Gas and aerosol emissions from Lascar volcano (Northern Chile): Insights into the origin of gases and their links with the volcanic activity. J. Volcanol. Geotherm. Res. 287, 51-67.

Meyer, C., Wunder, B., Meixner, A., Romer, R.L. and Heinrich, W. (2008) Boronisotope fractionation between tourmaline and fluid: an experimental reinvestigation. Contrib. Mineral. Petrol. 156, 259-267.

Pašava, J., Tornos, F. and Chrastný, V. (2014) Zinc and sulfur isotope variation in sphalerite from carbonate-hosted zinc deposits, Cantabria, Spain. Mineral. Deposita 49, 797-807. 
Rubin, A.M. (1995) Propagation of magma-filled cracks. Annual Review of Earth and Planetary Sciences 23, 287-336.

Shannon, R.D. (1976) Revised effective ionic radii and systematic studies of interatomic distances in halides and chalcogenides. Acta Cryst. A 32, 751-767.

Sossi, P.A., Nebel, O., O'Neill, H.S.C. and Moynier, F. (2018) Zinc isotope composition of the Earth and its behaviour during planetary accretion. Chem. Geol. $477,73-84$.

Symonds, R.B., Rose, W.I., Reed, M.H., Lichte, F.E. and Finnegan, D.L. (1987) Volatilization, transport and sublimation of metallic and non-metallic elements in high temperature gases at Merapi Volcano, Indonesia. Geochim. Cosmochim. Acta $51,2083-2101$.

Taran, Y.A., Hedenquist, J., Korzhinsky, M., Tkachenko, S. and Shmulovich, K. (1995) Geochemistry of magmatic gases from Kudryavy volcano, Iturup, Kuril Islands. Geochim. Cosmochim. Acta 59, 1749-1761.

Telus, M., Dauphas, N., Moynier, F., Tissot, F.L.H., Teng, F.-Z., Nabelek, P.I., Craddock, P.R. and Groat, L.A. (2012) Iron, zinc, magnesium and uranium isotopic fractionation during continental crust differentiation: The tale from migmatites, granitoids, and pegmatites. Geochim. Cosmochim. Acta 97, 247-265.

Thomas, R., Davidson, P., Rhede, D. and Leh, M. (2009) The miarolitic pegmatites from the Königshain: a contribution to understanding the genesis of pegmatites. Contrib. Mineral. Petrol. 157, 505.

Tosdal, R. (2001) Magmatic and structural controls on the development of porphyry $\mathrm{Cu} \pm \mathrm{Mo} \pm \mathrm{Au}$ deposits. Rev. in Econ. Geol. 14, 157-181. 
Toutain, J.-P., Sonke, J., Munoz, M., Nonell, A., Polvé, M., Viers, J., Freydier, R., Sortino, F., Joron, J.-L. and Sumarti, S. (2008) Evidence for $\mathrm{Zn}$ isotopic fractionation at Merapi volcano. Chem. Geol. 253, 74-82.

Urabe, T. (1987) The effect of pressure on the partitioning ratios of lead and zinc between vapor and rhyolite melts. Econ. Geol. 82, 1049-1052.

Wang, Z.-Z., Liu, S.-A., Liu, J., Huang, J., Xiao, Y., Chu, Z.-Y., Zhao, X.-M. and Tang, L. (2017) Zinc isotope fractionation during mantle melting and constraints on the Zn isotope composition of Earth's upper mantle. Geochim. Cosmochim. Acta 198, 151-167.

Wang, Z.-Z., Liu, S.-A., Liu, Z.-C., Zheng, Y.-C. and Wu, F.-Y. (2020) Extreme Mg and $\mathrm{Zn}$ isotope fractionation recorded in the Himalayan leucogranites. Geochim. Cosmochim. Acta 278, 305-321.

Wilkinson, J., Weiss, D., Mason, T. and Coles, B. (2005) Zinc isotope variation in hydrothermal systems: preliminary evidence from the Irish Midlands ore field. Econ. Geol. 100, 583-590.

Xia, Y., Li, S. and Huang, F. (2017) Iron and Zinc isotope fractionation during magmatism in the continental crust: Evidence from bimodal volcanic rocks from Hailar basin, NE China. Geochim. Cosmochim. Acta 213, 35-46.

Xu, L.-J., Liu, S.-A., Wang, Z.-Z., Liu, C. and Li, S. (2019) Zinc isotopic compositions of migmatites and granitoids from the Dabie Orogen, central China: Implications for zinc isotopic fractionation during differentiation of the continental crust. Lithos $324-325,454-465$.

Zajacz, Z., Halter, W.E., Pettke, T. and Guillong, M. (2008) Determination of fluid/melt partition coefficients by LA-ICPMS analysis of co-existing fluid and silicate melt 
inclusions: Controls on element partitioning. Geochim. Cosmochim. Acta 72, 2169-2197.

Zelenski, M., Malik, N. and Taran, Y. (2014) Emissions of trace elements during the 2012-2013 effusive eruption of Tolbachik volcano, Kamchatka: enrichment factors, partition coefficients and aerosol contribution. J. Volcanol. Geotherm. Res. $285,136-149$.

Zelenski, M.E., Fischer, T.P., de Moor, J.M., Marty, B., Zimmermann, L., Ayalew, D., Nekrasov, A.N. and Karandashev, V.K. (2013) Trace elements in the gas emissions from the Erta Ale volcano, Afar, Ethiopia. Chem. Geol. 357, 95-116. 


\section{Figure captions}

Fig. 1. Back-scattered electron (BSE) images of run products in the experiments: (a) basalt from run $\mathrm{Zn} 17$ after a run time of 7 days at $850{ }^{\circ} \mathrm{C}$ and $2 \mathrm{kbar}$. (b) andesite from run $\mathrm{Zn} 7$ after a run time of 7 days at $850{ }^{\circ} \mathrm{C}$ and $2 \mathrm{kbar}$. (c) dacite from run $\mathrm{Zn} 16$ after a run time of 7 days at $850^{\circ} \mathrm{C}$ and 2 kbar. (d) rhyolite dacite from run $\mathrm{Zn} 19$ after a run time of 7 days at $850{ }^{\circ} \mathrm{C}$ and $2 \mathrm{kbar}$. (e) rhyolite from run $\mathrm{Zn} 12$ after a run time of 10 days at $850{ }^{\circ} \mathrm{C}$ and $2 \mathrm{kbar}$. (f) haplogranite from run $\mathrm{Zn} 12$ after a run time of 13 days at $800{ }^{\circ} \mathrm{C}$ and 2 kbar. Abbreviations: cpx clinopyroxene; plg - plagioclase; phl - phlogopite; mag - magnetite; spl - spinel.

Fig. 2. The $\delta^{66} \mathrm{Zn}$ values in experimental magma products vs. in fluid products at at 700 to $900{ }^{\circ} \mathrm{C}$ and $2 \mathrm{kbar}$ with durations ranging from 7 days to 15 days. The results show the recovered fluids have higher $\delta^{66} \mathrm{Zn}$ values than the residue magmas, and their fractionation factors are quite comparable for the same starting materials.

Fig. 3. Isotopic fractionation values $\left(\Delta^{66} \mathrm{Zn}_{\text {fluid-magma }}\right)$ of $\mathrm{Zn}$ between fluid and magma as a function of (a) experimental durations from 7 to 15 days in a haplogranite, (c) salinity in the starting fluid $(1.75-7.0 \mathrm{wt} \% \mathrm{Cl})$ in a rhyolite, $(\mathrm{c})$ temperature from 700 to $900{ }^{\circ} \mathrm{C}$ in a haplogranite, (d) NBO/T of the starting materials, (e) rock compositions $(\mathrm{Al} /(0.5 \mathrm{~K}+\mathrm{Ca}+\mathrm{Fe})$ in mole), and (f) rock compositions $(\mathrm{Al} /(0.5 \mathrm{Na}+0.5 \mathrm{~K}+\mathrm{Ca})$ in mole $)$ at all conditions

Fig. 4. Partition coefficient $\left(\mathrm{D}_{\mathrm{Zn}}\right.$ fluid-magma) of $\mathrm{Zn}$ between fluid and magma as a function of (a) salinity in the starting fluid $(1.75-7.0 \mathrm{wt} \% \mathrm{Cl})$ in a rhyolite, (b) temperature from 700 to $900{ }^{\circ} \mathrm{C}$ in a haplogranite, (c) NBO/T of the starting materials, and $(\mathrm{d})$ rock composition $(\mathrm{Al} /(0.5 \mathrm{~K}+\mathrm{Ca}+\mathrm{Fe})$ in mole $)$ at all conditions. 
Fig. 5. (a) Rayleigh fractionation model of $\delta^{66} \mathrm{Zn}$ in fluids and magmas during magma degassing. A fractional degassing model was used and the initial $\delta^{66} \mathrm{Zn}$ values in the silicate magmas was assumed to be $0.20 \pm 0.05 \%$ (around the average $\mathrm{Zn}$ isotopic composition of Bulk Silicate Earth, according to Wang et al. (2017) and Sossi et al. (2018)). $\Delta^{66} \mathrm{Zn}_{\text {fluid-magma }}=0.2,0.4$ and $0.8 \%$ were used in the modelling. (b) A summary of $\mathrm{Zn}$ isotopic compositions for the igneous rocks and geological samples relevant to the magmatic fluids. $\mathrm{Zn}$ isotopic compositions of the igneous rocks are from Telus et al. (2012), Chen et al. (2013), Doucet et al. (2018), Xia et al. (2017), Huang et al. (2018) and Xu et al. (2019); Other samples' Zn isotopes are from John et al. (2008), Toutain et al. (2008), Chen et al. (2014) and Chiaradia et al. (2018). 


\section{Journal Pre-proofs}

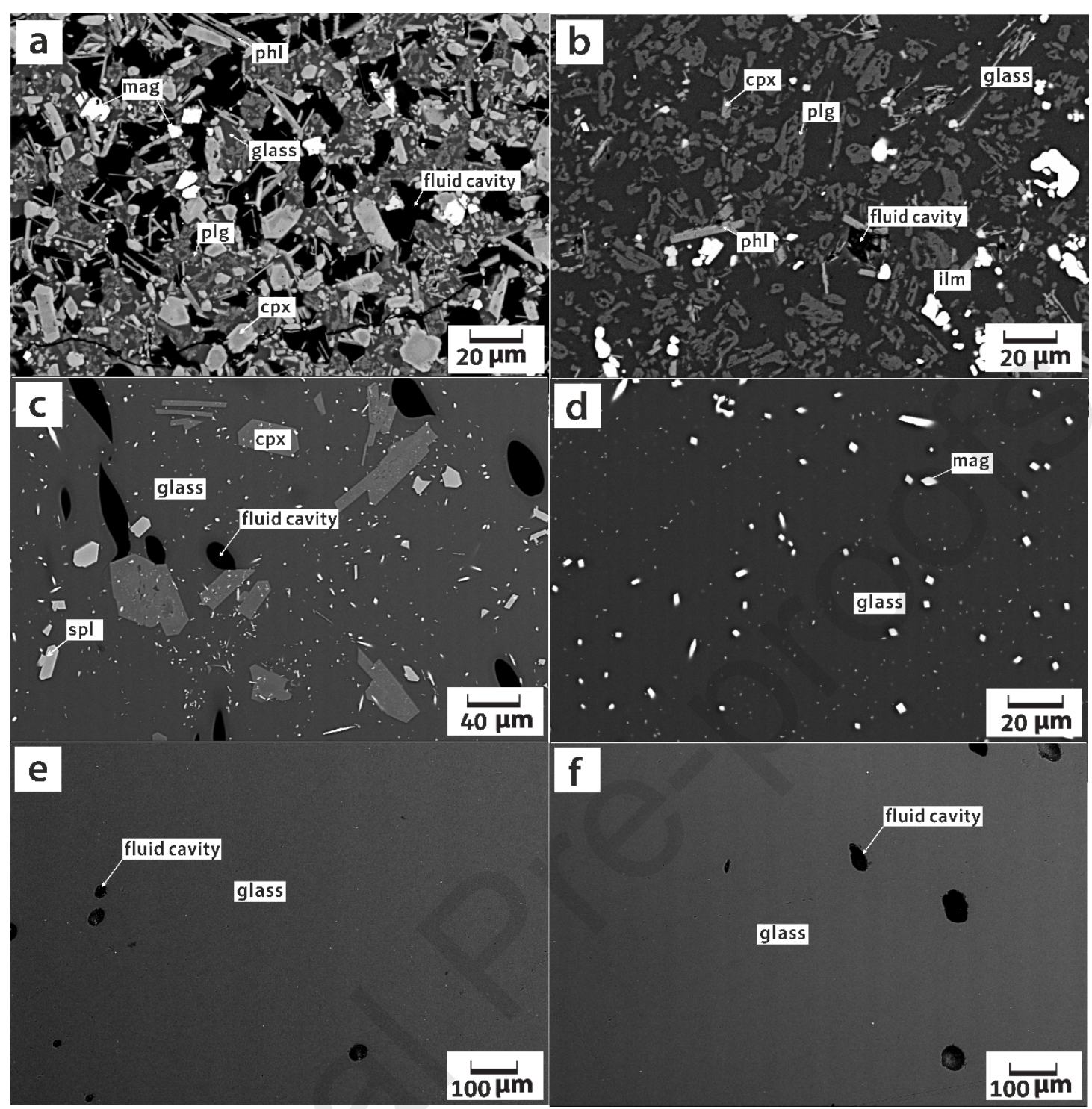

Fig. 1. Back-scattered electron (BSE) images of run products in the experiments: (a) basalt from run $\mathrm{Zn} 17$ after a run time of 7 days at $850^{\circ} \mathrm{C}$ and $2 \mathrm{kbar}$. (b) andesite from run $\mathrm{Zn} 7$ after a run time of 7 days at $850^{\circ} \mathrm{C}$ and $2 \mathrm{kbar}$. (c) dacite from run $\mathrm{Zn} 16$ after a run time of 7 days at $850^{\circ} \mathrm{C}$ and 2 kbar. (d) rhyolite dacite from run $\mathrm{Zn} 19$ after a run time of 7 days at $850^{\circ} \mathrm{C}$ and 2 kbar. (e) rhyolite from run $\mathrm{Zn} 12$ after a run time of 10 days at $850^{\circ} \mathrm{C}$ and 2 kbar. (f) haplogranite from run $\mathrm{Zn} 12$ after a run time of 13 days at $800{ }^{\circ} \mathrm{C}$ and 2 kbar. Abbreviations: cpx - clinopyroxene; plg - plagioclase; phl phlogopite; mag - magnetite; spl - spinel. 


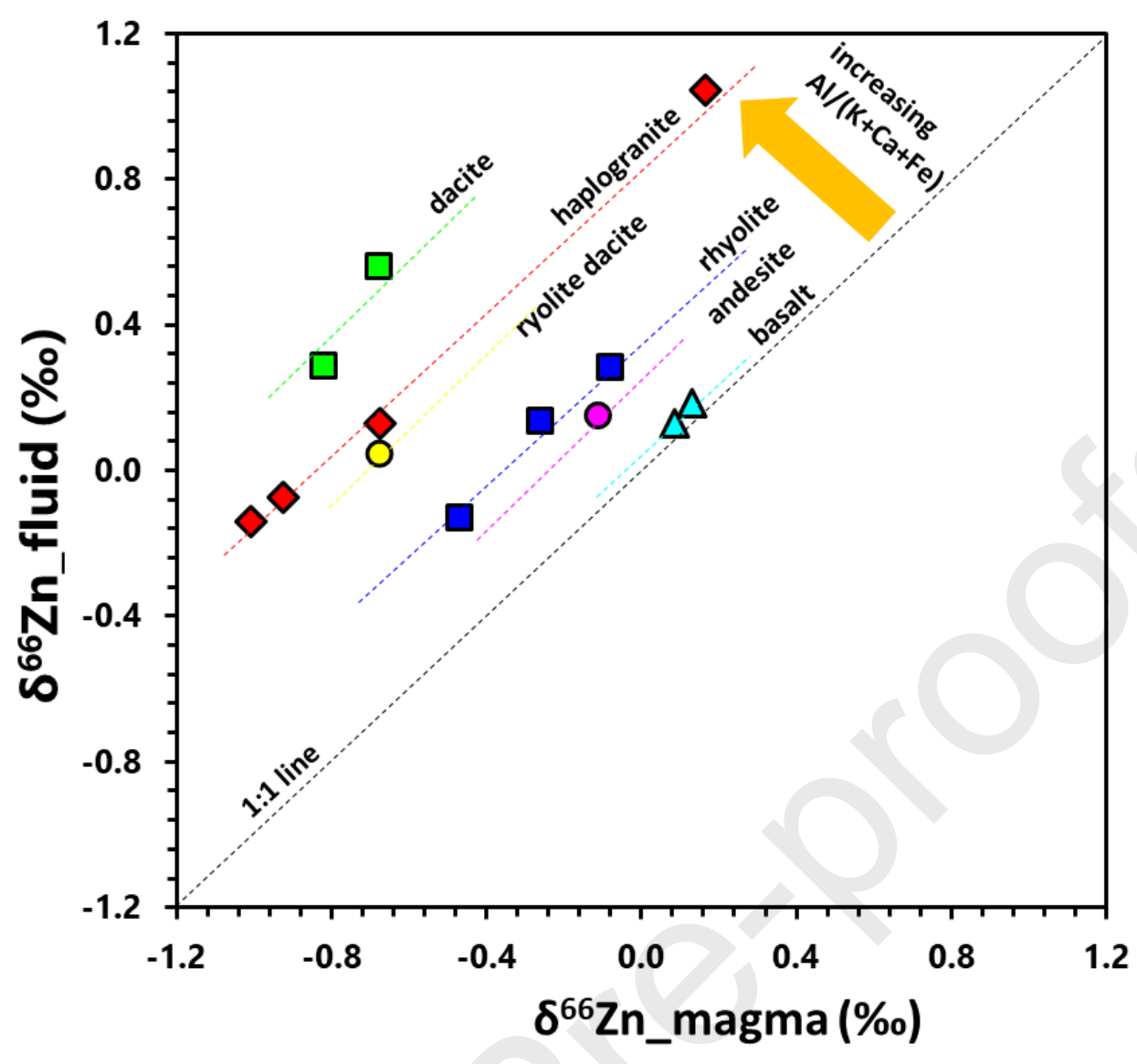

Fig. 2. The $\delta^{66} \mathrm{Zn}$ values in experimental magma products vs. in fluid products at at 700 to $900{ }^{\circ} \mathrm{C}$ and $2 \mathrm{kbar}$ with durations ranging from 7 days to 15 days. The results show the recovered fluids have higher $\delta^{66} \mathrm{Zn}$ values than the residue magmas, and their fractionation factors are quite comparable for the same starting materials. 

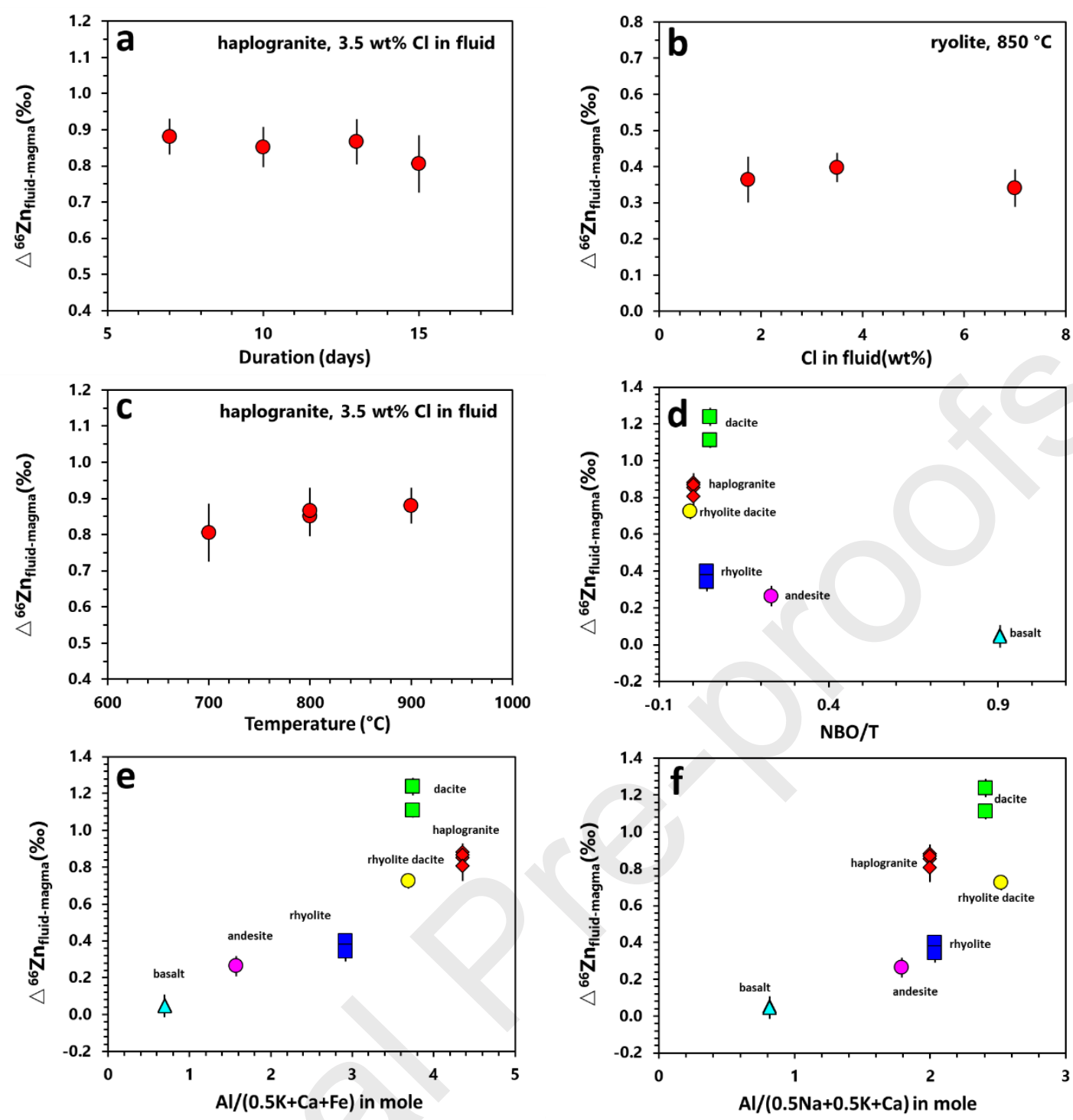

Fig. 3. Isotopic fractionation values ( $\left.\Delta^{66} \mathrm{Zn}_{\text {fluid-magma }}\right)$ of $\mathrm{Zn}$ between fluid and magma as a function of (a) experimental durations from 7 to 15 days in a haplogranite, (c) salinity in the starting fluid $(1.75-7.0 \mathrm{wt} \% \mathrm{Cl})$ in a rhyolite, (c) temperature from 700 to $900{ }^{\circ} \mathrm{C}$ in a haplogranite, (d) NBO/T of the starting materials, (e) rock compositions $(\mathrm{Al} /(0.5 \mathrm{~K}+\mathrm{Ca}+\mathrm{Fe})$ in mole $)$, and (f) rock compositions $(\mathrm{Al} /(0.5 \mathrm{Na}+0.5 \mathrm{~K}+\mathrm{Ca})$ in mole $)$ at all conditions. 

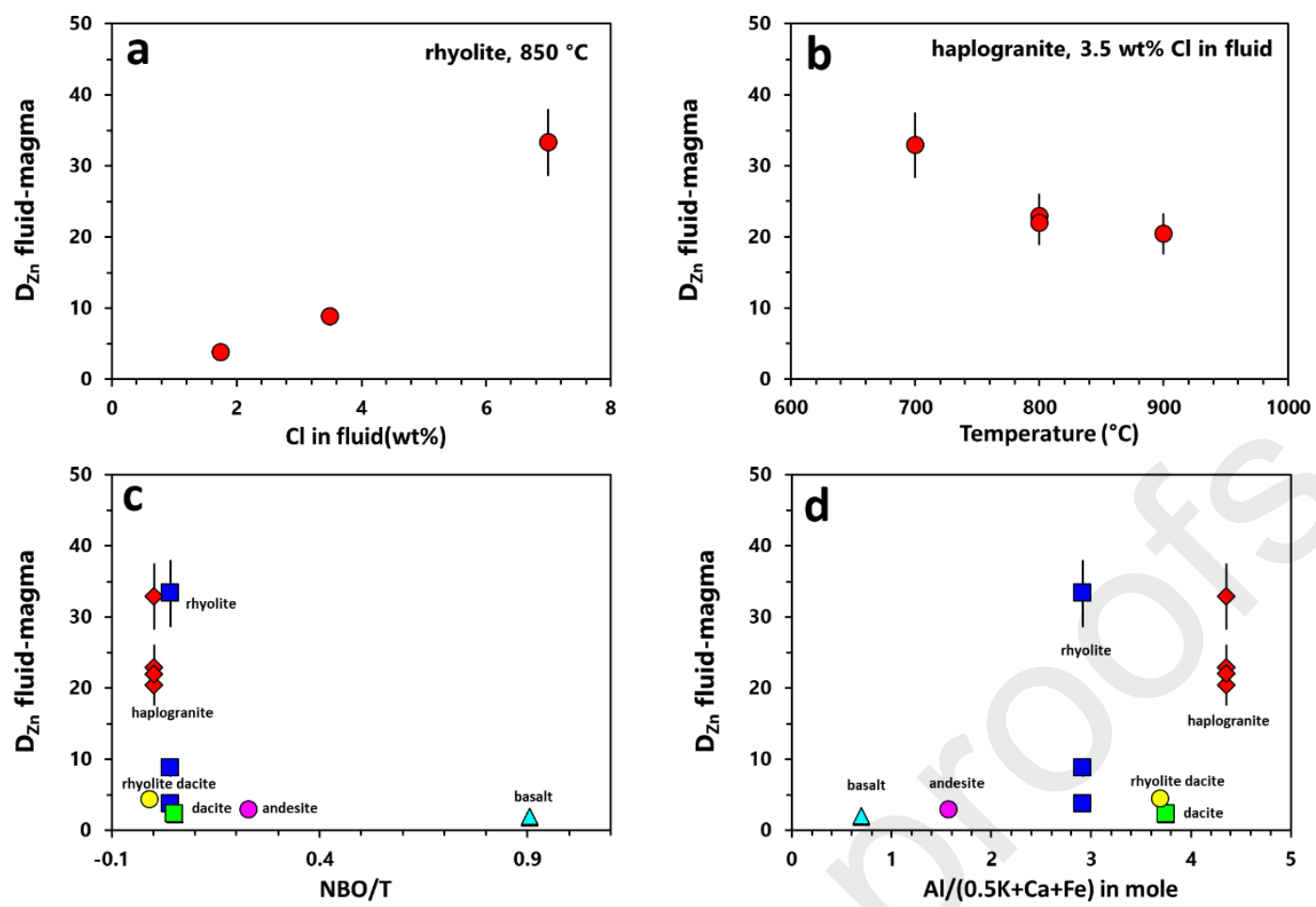

Fig. 4. Partition coefficient ( $\mathrm{D}_{\mathrm{Zn}}$ fluid-magma) of $\mathrm{Zn}$ between fluid and magma as a function of (a) salinity in the starting fluid $(1.75-7.0 \mathrm{wt} \% \mathrm{Cl})$ in a rhyolite, (b) temperature from 700 to $900{ }^{\circ} \mathrm{C}$ in a haplogranite, (c) NBO/T of the starting materials, and $(\mathrm{d})$ rock composition $(\mathrm{Al} /(0.5 \mathrm{~K}+\mathrm{Ca}+\mathrm{Fe})$ in mole $)$ at all conditions. 

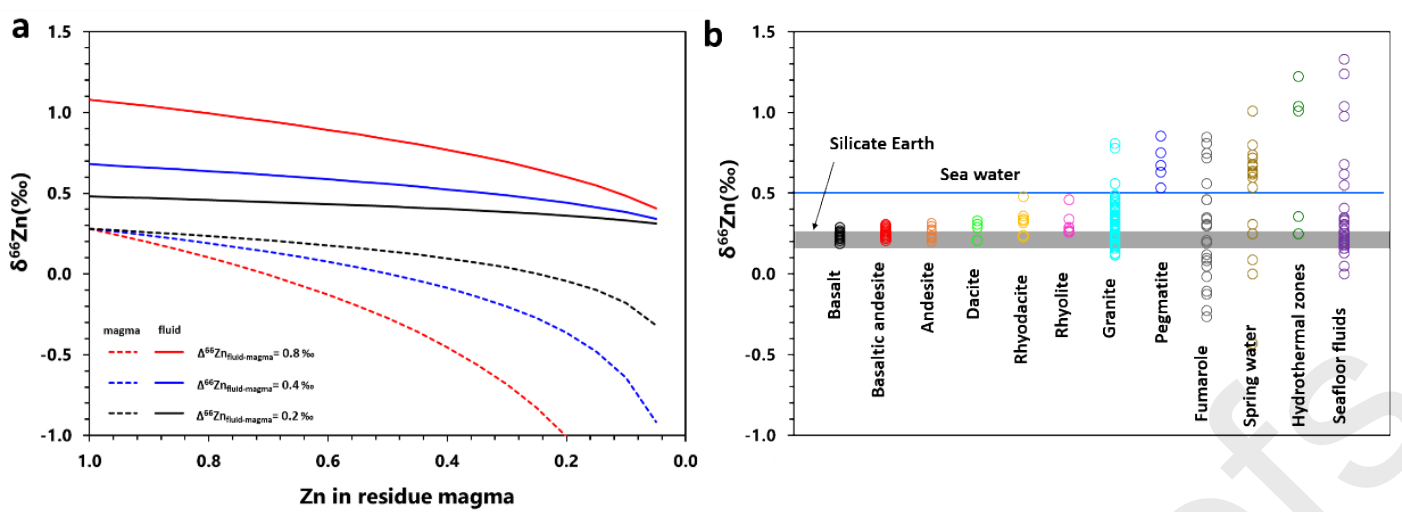

Fig. 5. (a) Rayleigh fractionation model of $\delta^{66} \mathrm{Zn}$ in fluids and magmas during magma degassing. A fractional degassing model was used and the initial $\delta^{66} \mathrm{Zn}$ values in the silicate magmas was assumed to be $0.20 \pm 0.05 \%$ (around the average $\mathrm{Zn}$ isotopic composition of Bulk Silicate Earth, according to Wang et al. (2017) and Sossi et al. (2018)). $\Delta^{66} \mathrm{Zn}_{\text {fluid-magma }}=0.2,0.4$ and $0.8 \%$ were used in the modelling. (b) A summary of $\mathrm{Zn}$ isotopic compositions for the igneous rocks and geological samples relevant to the magmatic fluids. $\mathrm{Zn}$ isotopic compositions of the igneous rocks are from Telus et al. (2012), Chen et al. (2013), Doucet et al. (2018), Xia et al. (2017), Huang et al. (2018) and Xu et al. (2019); Other samples' Zn isotopes are from John et al. (2008), Toutain et al. (2008), Chen et al. (2014) and Chiaradia et al. (2018).

Table 1

Compositions of starting materials. All oxides are in weight percent. 


\begin{tabular}{ccccccc} 
Element & basalt & andesite & dacite & $\begin{array}{c}\text { ryolite } \\
\text { dacite }\end{array}$ & ryolite & haplogranite \\
\hline $\mathrm{Na}_{2} \mathrm{O}$ & 2.3 & 4.26 & 5.4 & 3.6 & 4.1 & 3.9 \\
$\mathrm{MgO}$ & 10.6 & 1.53 & 1.5 & 0.3 & 0.28 & 0.02 \\
$\mathrm{Al}_{2} \mathrm{O}_{3}$ & 11.1 & 17.15 & 18.8 & 16.1 & 13.7 & 11.7 \\
$\mathrm{SiO}_{2}$ & 54.1 & 58.8 & 66.0 & 72.2 & 73.4 & 79.5 \\
$\mathrm{~K}_{2} \mathrm{O}$ & 4.1 & 2.92 & 2.1 & 3.4 & 4.3 & 4.9 \\
$\mathrm{CaO}$ & 10.4 & 4.94 & 2.5 & 1.8 & 1.15 & \\
$\mathrm{TiO}_{2}$ & 1.0 & 1.05 & 0.7 & 0.6 & 0.27 & 0.02 \\
$\mathrm{FeO}_{\mathrm{t}}$ & 6.1 & 6.77 & 2.3 & 1.3 & 1.86 & 0.04 \\
\hline
\end{tabular}

\section{Table 2}

Experimental conditions and results overview.

\begin{tabular}{|c|c|c|c|c|c|c|c|c|}
\hline run No. & $\begin{array}{c}\mathrm{T} \\
\left({ }^{\circ} \mathrm{C}\right)\end{array}$ & $\begin{array}{c}\mathrm{P} \\
\text { (kbar) }\end{array}$ & $\begin{array}{l}\text { duration } \\
\text { (days) }\end{array}$ & $\begin{array}{l}\text { starting } \\
\text { material }\end{array}$ & $\begin{array}{c}\mathrm{Cl} \text { in } \\
\text { solution } \\
(\mathrm{wt} \%)\end{array}$ & $\delta^{66} \mathrm{Zn} \_$magma & 2SD & $\delta^{68} \mathrm{Zn} \_$magr \\
\hline Zn04 & 850 & 2 & 7 & ryolite & 1.75 & -0.08 & 0.04 & -0.15 \\
\hline $\mathrm{Zn} 12$ & 850 & 2 & 10 & ryolite & 3.5 & -0.26 & 0.02 & -0.52 \\
\hline $\mathrm{Zn} 05$ & 850 & 2 & 7 & ryolite & 7 & -0.47 & 0.02 & -0.90 \\
\hline $\mathrm{Zn} 08$ & 900 & 2 & 7 & haplogranite & 3.5 & 0.17 & 0.01 & 0.31 \\
\hline Zn09 & 800 & 2 & 10 & haplogranite & 3.5 & -0.92 & 0.02 & -1.79 \\
\hline $\mathrm{Zn} 13$ & 800 & 2 & 13 & haplogranite & 3.5 & -1.01 & 0.04 & -2.00 \\
\hline Zn10 & 700 & 2 & 15 & haplogranite & 3.5 & -0.67 & 0.03 & -1.30 \\
\hline Zn17 & 850 & 2 & 7 & basalt & 3.5 & 0.13 & 0.01 & 0.22 \\
\hline Zn11 & 850 & 2 & 7 & basalt & 3.5 & 0.08 & 0.03 & 0.19 \\
\hline $\mathrm{Zn} 07$ & 850 & 2 & 7 & andesite & 3.5 & -0.11 & 0.03 & -0.20 \\
\hline Zn16 & 850 & 2 & 7 & dacite & 3.5 & -0.82 & 0.03 & -1.55 \\
\hline $\mathrm{Zn} 16.1$ & 850 & 2 & 10 & dacite & 3.5 & -0.68 & 0.04 & -1.29 \\
\hline Zn19 & 850 & 2 & 7 & ryolite dacite & 3.5 & -0.68 & 0.01 & -1.15 \\
\hline
\end{tabular}

Table 3

Recovery solid phase (quenched magma) and fluid compositions analyzed by ICP-MS.

\begin{tabular}{|c|c|c|c|c|c|c|c|c|c|c|}
\hline \multirow{2}{*}{$\begin{array}{l}\text { Sample } \\
\text { ppm }\end{array}$} & \multicolumn{2}{|c|}{$\mathrm{Zn} 4$} & \multicolumn{2}{|c|}{$\mathrm{Zn} 12$} & \multicolumn{2}{|c|}{ Zn5 } & \multicolumn{2}{|c|}{$\mathrm{Zn} 8$} & \multicolumn{2}{|c|}{$\mathrm{Zn} 9$} \\
\hline & magma & fluid & magma & fluid & magma & fluid & magma & fluid & magma & fluid \\
\hline $\mathrm{Li}$ & 59 & 11.2 & 52 & 11.7 & 42 & 23.9 & 2 & 3.4 & 1.9 & 1.3 \\
\hline $\mathrm{Na}$ & 25,310 & 4,080 & 21,689 & 5,362 & 17,654 & 9,852 & 21,824 & 919 & 20,758 & 2,387 \\
\hline $\mathrm{Mg}$ & 1578 & 15 & 1502 & 27 & 1374 & 100 & 98 & n.a. & 92 & n.a. \\
\hline $\mathrm{Al}$ & 71,680 & 179 & 66,071 & 256 & 66,891 & 434 & 59,602 & 175 & 63,340 & 270 \\
\hline
\end{tabular}




\begin{tabular}{lcccccccccc}
$\mathrm{K}$ & 31,445 & 4,146 & 26,418 & 6,288 & 22,034 & 11,413 & 32,705 & 592 & 31,093 & 2,696 \\
$\mathrm{Ca}$ & 2,970 & 36 & 2,681 & 44 & 2,607 & 159 & 156 & 12 & 125 & 2 \\
$\mathrm{Sc}$ & 4.6 & n.a. & 4.4 & n.a. & 4.1 & n.a. & 1.0 & n.a. & 1.0 & n.a. \\
$\mathrm{Ti}$ & 1,009 & 11 & 1,256 & 7.3 & 901 & 8.4 & 133 & 1.4 & 135 & 1.0 \\
$\mathrm{~V}$ & 3.9 & n.a. & 3.2 & n.a. & 3.1 & n.a. & n.a. & n.a. & n.a. & n.a. \\
$\mathrm{Cr}$ & 2.0 & n.a. & n.a. & n.a. & n.a. & n.a. & n.a. & n.a. & 0.65 & n.a. \\
$\mathrm{Mn}$ & 254 & 70 & 173 & 107 & 82 & 202 & 4 & 1 & 3 & 1 \\
$\mathrm{Fe}$ & 10,668 & 2,075 & 7,318 & 4,718 & 3,326 & 8,471 & 216 & 41 & 397 & 136 \\
$\mathrm{Co}$ & 6.9 & 5.6 & 7.2 & 11 & 3.9 & 15 & 92 & 6 & 3 & 3 \\
$\mathrm{Ni}$ & 95 & 48 & 148 & 167 & 83 & 530 & 398 & 79 & 246 & 326 \\
$\mathrm{Zn}$ & 175 & 661 & 98 & 864 & 29 & 967 & 45 & 920 & 26 & 892 \\
$\mathrm{Rb}$ & 139 & 20 & 113 & 31 & 97 & 57 & 2 & 0.5 & 2 & 0.3 \\
$\mathrm{Sr}$ & 120 & 11 & 110 & 12 & 106 & 16 & 125 & 11 & 129 & 11 \\
$\mathrm{Ba}$ & 887 & 81 & 824 & 67 & 804 & 111 & 36 & 74 & 36 & 46 \\
\hline n.a.- not analyzed & & & & & & & & &
\end{tabular}




\section{Declaration of competing interest}

The authors declare that they have no known competing financial interests or personal relationships that could have appeared to influence the work reported in this paper. 